\title{
CHARACTERIZATION OF THE INTERACTION BETWEEN GLAZES AND CERAMIC BODIES
}

\author{
MÁRIA KAVANOVÁ*, "ALEXANDRA KLOUŽKOVÁ*, JAROSLAV KLOUŽEK** \\ *Department of Glass and Ceramics, University of Chemistry and Technology Prague, \\ Technická 5, 16628 Prague, Czech Republic \\ **Laboratory of Inorganic Materials, Joint Workplace of the University of \\ Chemistry and Technology Prague and the Institution of Rock Structure and Mechanics ASCR, v.v.i., \\ Technická 5, 16628 Prague, Czech Republic \\ "E-mail: alexandra.klouzkova@vscht.cz
}

Submitted December 12, 2016; accepted April 10, 2017

\begin{abstract}
Keywords: Glazes, Ceramics, Thermal analysis, Coefficients of the thermal expansion, Dilatometry
The paper presents the study of stress relations of ceramic body - glaze systems of model and real, both historical and contemporary ceramics. The samples were characterized in terms of chemical composition, linear thermal expansion coefficient and degradation effects. Calculations of stress relations between the body and glaze were firstly performed on model samples. Compresive or tensile stresses were created in the surface layers of model systems using various model glazes. The same procedure for calculating stress states was subsequently applied to historical and contemporary ceramic products exhibiting different types of damage. The possibilities of using TMA measurement and CTE calculations using additive quotients has been verified. Calculated results provide relevant information about the accordance of the glaze-ceramic body and for the characterization of surface defects.
\end{abstract}

\section{INTRODUCTION}

Glaze act as smooth, relatively thin glassy coating of ceramic body which is effectively bonded to its substrate [1]. The main reason for the use of glazes as surface coatings of ceramic materials is their relatively high chemical resistance and aesthetic aspects. Glaze coatings are applied on the surface of whiteware, dental ceramics, building ceramics or floor and roof tiles etc. [2-7]. All these products are expected to be of high quality and resistant to various types of corrosion without loss of utility properties. Therefore glazes must to some extent withstand the contact with water, acid or alkali media and other aggressive environments [8-9]. Chemical resistance of glassy coatings is a significant parameter of the utility of many ceramic products. The first step in the application of glazed ceramics is its trouble-free preparation. In addition to respecting technological process, the accordance of the coefficients of thermal expansion of the surface coating and ceramic body is also essential. Glazes and ceramic bodies are in close contact and react chemically and physically during firing. Chemical reactions of individual components take place, change the chemical composition and if the firing process is long enough lead to the formation of interlayers on interfaces. Characterization of the interaction between glazes and ceramic bodies can provide information about application features, firing processes and range and sign of stress in the glaze layer. Glazed ceramic products often exhibit residual stresses due to manufacturing process (Figure 1) [5]. These residual stresses could be caused by inhomogeneity in microstructure and by presence of microscopic defects [5]. Glaze defects are often caused by improper stresses within glaze layers (tension, compression) or by changes in ceramic bodies (moisture

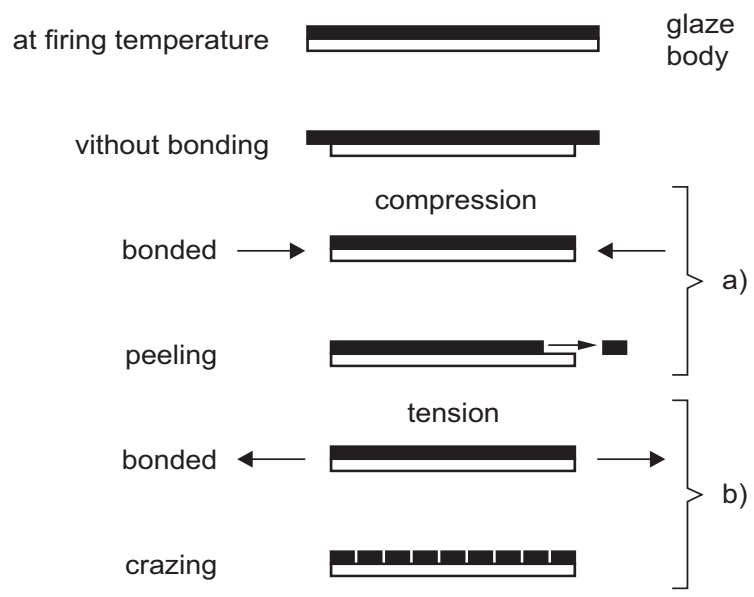

Figure 1. Residual stresses in glazed ceramic products. Glaze thermal expansion coefficient is: a) lower or b) higher than that of the body. 
expansion, rehydration) and glaze layers during usage or improper storage of ceramic products. The glaze defects could be divided into primary and secondary $[1,10]$. Primary (instant) defects are caused by poor glaze fit or technological processes. Secondary (delayed) defects are results of moisture expansion of the substrate or inappropriate storage conditions. All these defects can lead to the loss of utility properties or to the deterioration of the ceramic product.

Stable glass surfaces finishing of a ceramic body have aesthetic and protective function on the ceramic body but they have to create an effective bond with their substrates. A glaze should be free from faults to serve its purpose. To propose a suitable surface finishing for a specific ceramic body, it is necessary to know basic characteristics - properties of a glaze, a ceramic body and of course stress relation of a final glaze - ceramic body system. The main factor that influence stress relations between a glaze and a ceramic body is the difference in coefficients of thermal expansion. The average stress $\sigma$ in $\mathrm{MPa}$ (compressive - negative, tensile-positive) in the glaze and body layers may be calculated using relations $[11,12]$ :

$$
\begin{gathered}
\sigma_{g}=\frac{\left(\alpha_{s}-\alpha_{g}\right)}{\frac{1-\mu_{s}}{E_{s}}+\frac{1-\mu_{g}}{E_{g}} \times \frac{h_{s}}{h_{g}}} \times \Delta T \\
\sigma_{s}=\frac{\left(\alpha_{g}-\alpha_{s}\right)}{\frac{1-\mu_{g}}{E_{g}}+\frac{1-\mu_{s}}{E_{s}} \times \frac{h_{g}}{h_{s}}} \times \Delta T
\end{gathered}
$$

Subscripts $g$ and $s$ indicate glaze and body. $\alpha$ is linear thermal expansion coefficient, $\mu$ is Poisson ratio, $E$ is Young`s modulus and $h$ is thickness of the layer of glaze and body.

Extensive stress within a glaze layer develops as a consequence of differences in coefficients of thermal expansion during cooling process after firing or during long-term usage of a ceramic product. The formation of defects within a glaze layer is influenced by the extent and type of a stress. The evaluation of stress relations of the glaze - ceramic body system is important for the characterization of contemporary ceramic production (e.g. roof tile production etc.) however becomes interesting for determining the origin of defects of archaeological ceramic fragments and historical ceramics.

The present work deals with the characterization of surface defects and evaluation of stress relations between ceramic bodies and glazes for both historical and contemporary samples.

\section{EXPERIMENTAL}

The first part of the study is aimed at the selected model systems of ceramic body (St), two model lead glazes (G425, G432), one lead-free glaze (G430) and one lead frit (A2912) which is the semi-product of ceramic glaze technology. The second part involves the investigation of real ceramic body - glaze systems. The group of presented real systems composed of historical (S5) and contemporary $(\mathrm{KH})$ ceramic stove tile, historical floor tile (B21a) and contemporary roof tile (ceramic body $\mathrm{H}$ and glaze $\mathrm{Gr}$ ).

The model systems were selected due to the similarities to the real historical or contemporary glazes. They simulate situations occurring during long-term use or storage of the glazed ceramic products.

Chemical composition of ceramic bodies and glazes was measured by X-ray fluorescence analysis (XRF) carried out with ARL 9400 XP sequential WD-XRF spectrometer equipped with a $\mathrm{Rh}$ anode $\mathrm{X}$-ray tube type 4GN fitted with $50-\mu \mathrm{m}$ Be window. Raw the data was treated with software WinXRF. The standardless analysis was undertaken with software Uniquant 4. The samples were analysed in the form of fine powders, which were ground in an agate mortar and well dried at $105^{\circ} \mathrm{C}$.

Thermal linear expansion coefficients of ceramic bodies, model glazes and glaze $\mathrm{Gr}$ were measured by dilatometer Linseis L75HS 1600C PT (DIL). The thermal expansion values of compact samples of ceramic bodies (size $20 \times 10 \times 8 \mathrm{~mm}$ ) and compact cylindrical samples of glazes $($ size $20 \times 5 \mathrm{~mm})$ were obtained in temperature range $25-700^{\circ} \mathrm{C}$ or $25^{\circ} \mathrm{C}$ - deformation temperature for glazes in helium flow. The heating rate of all measurements was $5^{\circ} \mathrm{C} \cdot \mathrm{min}^{-1}$.

Samples of real glazes were prepared by removing the layer from surfaces of final ceramic products using engraving saw Dremel 300 Series and refired in laboratory firing kiln to prepare a compact rectangular sample of glaze (size $10 \times 2 \mathrm{~mm}$ ). Thermal expansion values of such prepared samples were measured by thermomechanical analyser TMA CXO4R R.M.I. at the rate of $5^{\circ} \mathrm{C} \cdot \mathrm{min}^{-1}$ from ambient temperature to the deformation temperature of the glaze.

Characteristic temperatures and thermal expansion coefficients of the glazes were also calculated from chemical composition determined by XRF by using Priven-2000 calculation method of the glass properties information system SciGlass 6.7 [13].

For the stress calculation (relation 1 and 2), the temperature independent values $\mu_{g}=0.15, \mu_{s}=0.33, E_{g}=$ $=35 \mathrm{GPa}$ and $E_{s}=70 \mathrm{GPa}$ were used. Glaze and body layers thicknesses were chosen $h_{g}=200 \mu \mathrm{m}$ and $h_{s}=$ $=5000-20000 \mu \mathrm{m}$.

\section{RESULTS AND DISCUSSION}

The chemical compositions of ceramic bodies and glazes obtained by X-ray fluorescence are shown in Table 1 (main components) and Table 2 (admixtures).

Model systems 
Characterization of the interaction between glazes and ceramic bodies

Table 1. Semi-quantitative chemical composition of studies ceramic bodies and glazes - main components (wt. \%).

\begin{tabular}{lccccccccc}
\hline model systems & $\mathrm{SiO}_{2}$ & $\mathrm{Al}_{2} \mathrm{O}_{3}$ & $\mathrm{Fe}_{2} \mathrm{O}_{3}$ & $\mathrm{TiO}_{2}$ & $\mathrm{CaO}$ & $\mathrm{MgO}$ & $\mathrm{K}_{2} \mathrm{O}$ & $\mathrm{Na}_{2} \mathrm{O}$ & $\mathrm{PbO}$ \\
\hline glaze $\mathrm{G} 425$ & 22 & 7 & 0.3 & 14 & 0.2 & 0.1 & 0.2 & 0.9 & 49 \\
glaze $\mathrm{G} 430$ & 66 & 15 & 0.2 & 0.1 & 7 & 0.1 & 0.4 & 6 & 0.02 \\
glaze $\mathrm{A} 2912$ & 29 & 7 & 0.03 & 0.02 & 0.3 & 0.02 & 0.1 & 0.2 & 59 \\
glaze $\mathrm{G} 432$ & 38 & 8 & 2.3 & 0.1 & 0.6 & 0.1 & 0.6 & 0.9 & 46 \\
St & 61 & 25 & 5 & 0.9 & 0.7 & 1.4 & 2.5 & 0.6 & - \\
\hline \hline real systems & $\mathrm{SiO}_{2}$ & $\mathrm{Al}_{2} \mathrm{O}_{3}$ & $\mathrm{Fe}_{2} \mathrm{O}_{3}$ & $\mathrm{TiO}_{2}$ & $\mathrm{CaO}$ & $\mathrm{MgO}$ & $\mathrm{K}_{2} \mathrm{O}$ & $\mathrm{Na}_{2} \mathrm{O}$ & $\mathrm{PbO}^{2}$ \\
\hline glaze $\mathrm{Gr}$ & 63 & 12 & 2.2 & 0.2 & 1.5 & 0.8 & 1.7 & 5 & - \\
$\mathrm{H}$ & 62 & 18 & 6 & 0.8 & 7 & 2.3 & 2.9 & 0.6 & - \\
glaze KH & 45 & 5 & - & - & 2 & 0.5 & 2 & 1 & 35 \\
KH & 71 & 20 & 3.3 & 0.7 & 0.8 & 1.0 & 2.3 & 0.6 & - \\
glaze $\mathrm{B} 21 \mathrm{a}$ & 46 & 8 & 14 & 0.7 & 3 & 0.9 & 1.5 & 0.5 & 25 \\
B21a & 72 & 16 & 4 & 0.9 & 1.6 & 1.3 & 2.7 & 1.0 & 0.2 \\
glaze $\mathrm{S} 5$ & 14 & 2.6 & 1.7 & 0.2 & 7.8 & 0.3 & 0.3 & 0.2 & 55 \\
S5 & 61 & 32 & 2.0 & 1.4 & 0.8 & 0.4 & 1.6 & 0.6 & 0.1 \\
\hline
\end{tabular}

Table 2. Semi-quantitative chemical composition of studies ceramic bodies and glazes - admixtures (wt. \%).

\begin{tabular}{|c|c|c|c|c|c|c|c|c|c|c|c|c|c|c|c|c|c|}
\hline $\begin{array}{l}\text { model } \\
\text { systems }\end{array}$ & $\mathrm{P}_{2} \mathrm{O}_{5}$ & $\mathrm{SO}_{3}$ & $\mathrm{Cl}$ & $\mathrm{V}_{2} \mathrm{O}_{5}$ & $\mathrm{Cr}_{2} \mathrm{O}_{3}$ & $\mathrm{MnO}$ & $\mathrm{Co}_{2} \mathrm{O}_{3}$ & $\mathrm{NiO}$ & $\mathrm{CuO}$ & $\mathrm{ZnO}$ & $\mathrm{Sb}_{2} \mathrm{O}_{3}$ & $\mathrm{BaO}$ & $\mathrm{ZrO}_{2}$ & $\mathrm{Rb}_{2} \mathrm{O}$ & $\mathrm{SrO}$ & $\mathrm{SnO}_{2}$ & $\mathrm{As}_{2} \mathrm{O}_{3}$ \\
\hline $\begin{array}{l}\text { glaze } \\
\text { G425 }\end{array}$ & 0.02 & - & - & 0.1 & 0.01 & - & - & - & 3.5 & 0.03 & - & - & 0.1 & - & - & 3.4 & 0.03 \\
\hline $\begin{array}{l}\text { glaze } \\
\text { G430 }\end{array}$ & 0.02 & -0 & 0.03 & - & 0.8 & - & - & - & - & 1.0 & - & 0.1 & 3.7 & - & - & - & - \\
\hline $\begin{array}{l}\text { glaze } \\
\text { A2912 }\end{array}$ & 0.01 & - & - & - & - & - & - & - & - & 0.1 & - & - & 0.1 & 0.01 & 0.01 & - & 0.03 \\
\hline $\begin{array}{l}\text { glaze } \\
\text { G432 }\end{array}$ & 0.02 & - & - & - & 0.01 & 0.4 & - & - & 1.4 & 1.3 & - & - & 0.01 & 0.02 & - & - & 0.04 \\
\hline $\mathrm{St}$ & 0.1 & 0.01 & $-\quad 0$ & 0.02 & 0.01 & 0.1 & - & - & - & - & - & - & 0.1 & - & 0.01 & - & - \\
\hline $\begin{array}{l}\text { real } \\
\text { systems }\end{array}$ & $\mathrm{P}_{2} \mathrm{O} 5$ & $\mathrm{SO}_{3}$ & $\mathrm{Cl}$ & $\mathrm{V}_{2} \mathrm{O}_{5}$ & ${ }_{5} \mathrm{Cr}_{2} \mathrm{O}_{3}$ & $\mathrm{MnO}$ & $\mathrm{Co}_{2} \mathrm{O}_{3}$ & $\mathrm{NiO}$ & $\mathrm{CuO}$ & $\mathrm{ZnO}$ & $\mathrm{Sb}_{2} \mathrm{O}_{3}$ & $\mathrm{BaO}$ & $\mathrm{ZrO}_{2}$ & $\mathrm{Rb}_{2} \mathrm{O}$ & $\mathrm{SrO}$ & $\mathrm{SnO}_{2}$ & $\mathrm{As}_{2} \mathrm{O}_{3}$ \\
\hline glaze $\mathrm{Gr}$ & 0.1 & - & 0.02 & - & 2.3 & 0.1 & 0.2 & 0.4 & - & 2.1 & - & 2.2 & 0.6 & - & 3.4 & 0.04 & - \\
\hline $\mathrm{H}$ & 0.1 & 0.2 & - & 0.03 & 0.01 & 0.1 & - & - & - & - & - & 0.1 & 0.04 & - & 0.03 & - & - \\
\hline glaze KH & 0.2 & 1 & - & - & - & - & - & - & 4 & 0.1 & 5 & - & - & - & - & - & - \\
\hline KH & 0.1 & 0.03 & 0.01 & 0.02 & 0.02 & 0.03 & - & - & - & - & - & 0.03 & 0.03 & - & - & - & - \\
\hline glaze B21a & a 0.3 & 0.5 & - & - & - & - & - & - & 0.1 & 0.03 & - & - & 0.01 & 0.05 & 0.02 & 0.3 & - \\
\hline B21a & 0.2 & - & - & - & - & 0.1 & - & - & - & - & - & 0.1 & 0.1 & - & 0.02 & - & - \\
\hline glaze S5 & 11 & 0.7 & 1.4 & 0.4 & - & 4.1 & - & - & 0.2 & 0.04 & 0.2 & - & - & - & - & - & - \\
\hline S5 & 0.2 & - & - & 0.02 & 0.01 & 0.01 & - & - & - & 0.01 & - & 0.02 & 0.1 & - & 0.01 & - & - \\
\hline
\end{tabular}

The model glazes were directly selected with regard to the type of glazes of real systems. The glazes G425 and G432 are commercially available lead glazes containing 49 and 46 wt. \% PbO. The glaze G430 is frit lead free glaze with $\mathrm{SiO}_{2}$ as dominating component, which is similar to contemporary building ceramics. The sample A2912 is the frit containing 59 wt. \% PbO using as a semi-product in artistic ceramic technology.

Figure 2 presents relative expansion curves of ceramic body and model glazes. Simple qualitative comparison between thermal expansion coefficients of the body $\left(\alpha_{s}\right)$ and the glaze $\left(\alpha_{g}\right)$ shows that glazes G430 and A2912 exhibit slight compressive stress $\left(\alpha_{s}>\alpha_{g}\right)$ which is the suitable for preventing all the negative circumstances during their application. The layer of the glaze G432 appear to have tensile stress $\left(\alpha_{s}<\alpha_{g}\right)$ that leads to the formation of failure pattern called crazing. This type of defect is already reflected during cooling process and could be in some type of ceramics needed especially in stove tile production. The analogical effect of tensile stress within the glaze was found on the glaze G425. The tension within the glaze G425 leads to the cracking due to a higher difference between glaze and body thermal expansion coefficients.

Figure 3 shows calculated stress relations glaze- 
body using equations (1) and (2). The glazes G430 and A2912 show slight compressive stress $\left(\sigma_{g}=-0.5 \mathrm{MPa}\right)$ at room temperature, which have a positive influence on the final product. Surface layer of ceramic body has tensile stress $\sigma_{s}=11.6$ and 12.1, thermal expansion mismatch is 12.1 and $12.5 \mathrm{MPa}$. The glaze G432 exhibits slight tensile stress $\left(\sigma_{g}=1.3 \mathrm{MPa}\right)$ which leads to the crazing pattern within the glaze. The sample G425 gives elevated tensile stress value $\left(\sigma_{g} \quad 2.6 \mathrm{MPa}\right)$ and is not suitable for application with studied ceramic body St.

The samples of lead frit A2912 were used for the comparison of the values of coefficients of thermal expansions (CTE) which could be obtained by different ways. Figure 4 compares relative expansion curves measured by dilatometer and thermomechanical analyser. The values indicate good agreement between both experimental methods. Figure 5 shows the values of CTE which were collected during measurement of two diffe-

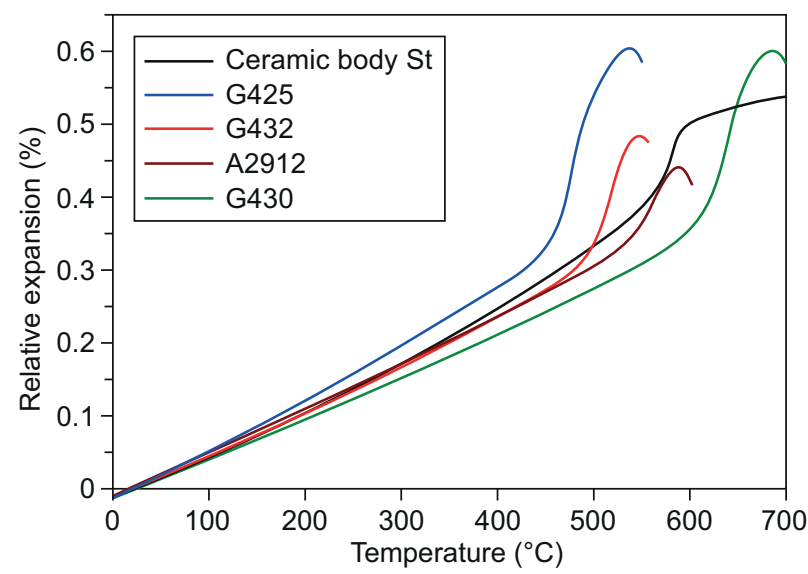

Figure 2. Relative expansion curves of model ceramic body (St) and glazes G425 (1), G432 (2), A2912 (3) and G430 (4).

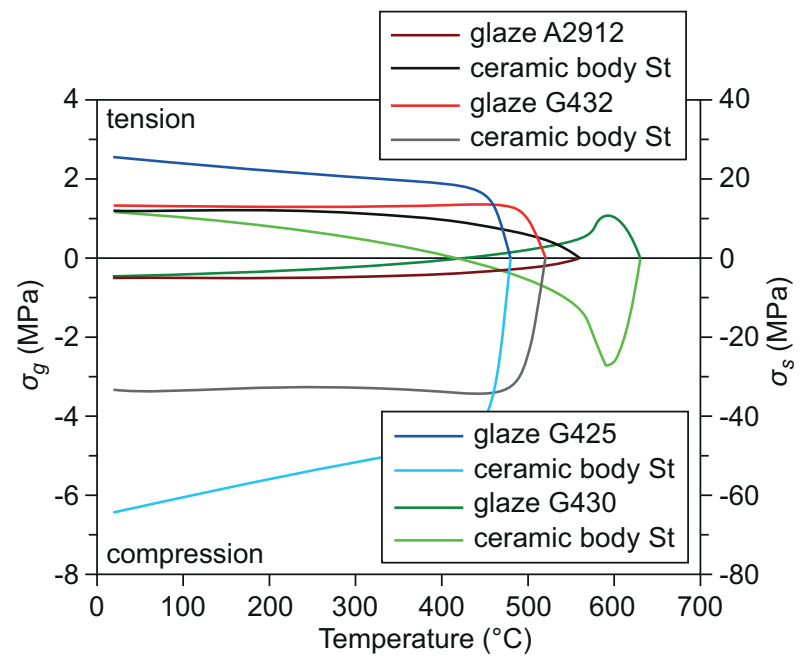

Figure 3. Stress relations of model systems ceramic body (St) and glazes G425 (1), G432 (2), A2912 (3) and G430 (4), glaze and body layers thicknesses were chosen $h_{g}=200 \mu \mathrm{m}$ and $h_{s}=5000 \mu \mathrm{m}$. rent samples (average values from 5 measurements of each of the samples) by dilatometer and calculated by SciGlass program using chemical composition of three main components - $\mathrm{PbO}-\mathrm{SiO}_{2}-\mathrm{Al}_{2} \mathrm{O}_{3}$ (blue dots), all components (orange dots). The range of the values of CTE is relatively little significant and confirms the suitability of using of calculated CTEs for evaluation of stress relations. Value deviation for individual measurements and calculation do not exceed 10 rel. \%.

\section{Real systems}

\section{Contemporary glazed ceramic stove $\mathrm{KH}$}

The first presented real glaze-ceramic body system is the contemporary glazed stove tile which was degraded fractionally by crazing as it was supposed after firing. This phenomenon was confirmed by measured and calculated relative expansions (Figure 6).

However the opposite effect of peeling occur on the surface of the tile after application. The glaze was in balancing tensile stress after firing, which was reduced

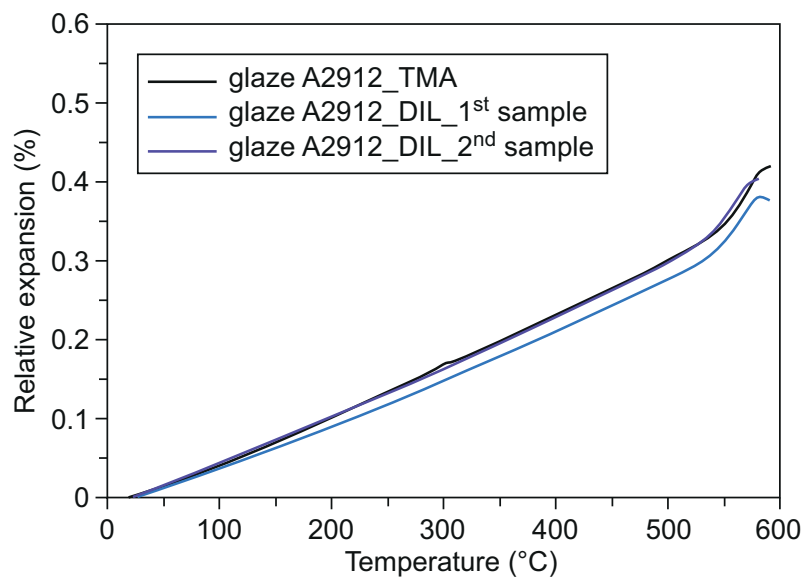

Figure 4. Comparison of relative expansion curves of the lead frit A2912 measured by dilatometer and thermomechanical analyser.

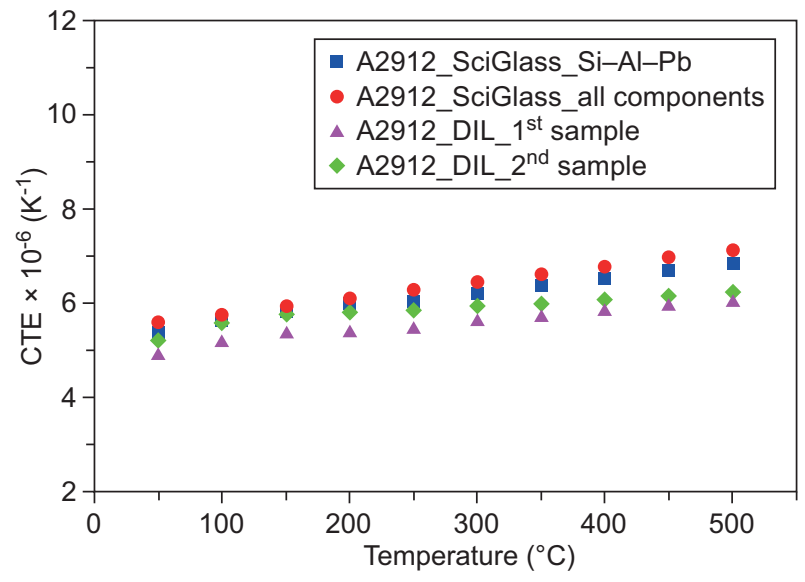

Figure 5. Comparison of calculated and measured values of CTE. 


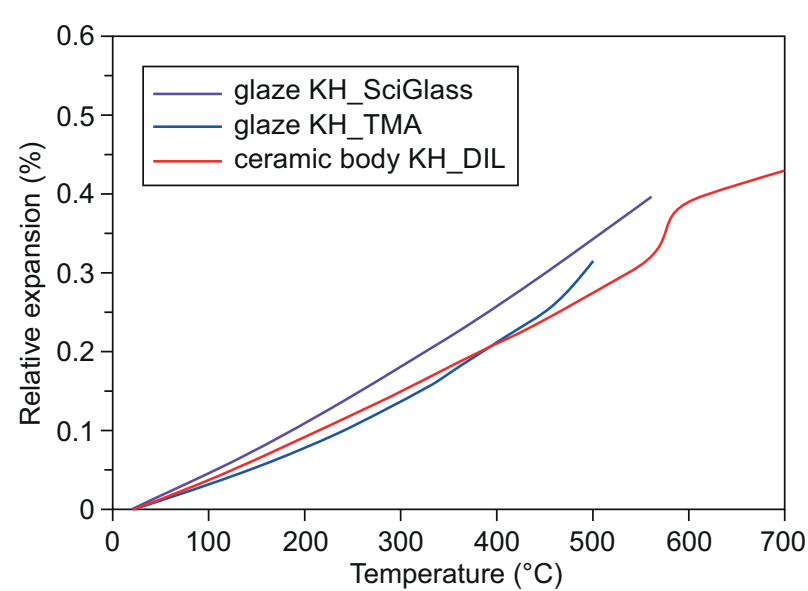

Figure 6. Relative expansion curves of ceramic body and glaze $\mathrm{KH}$ of contemporary ceramic stove.

significantly during usage due to the increased expansion of its body. The stress relation calculation presented in Figure 7 shows that the body stress so extensive. The compressive stress of the ceramic body $(-18.6 \mathrm{MPa})$ decreased the tension of the glaze $(0.05 \mathrm{MPa})$ to some extent and leads to its shivering. The stress of the glaze $\mathrm{KH}$ generated during the period of application of the final tile product exceeded the strength of adhesion between the glaze and the substrate.

The surface finishing was subjected to microscopic evaluation. Typical failure of cracks in the glaze extending from the outer surface to the glaze - ceramic body

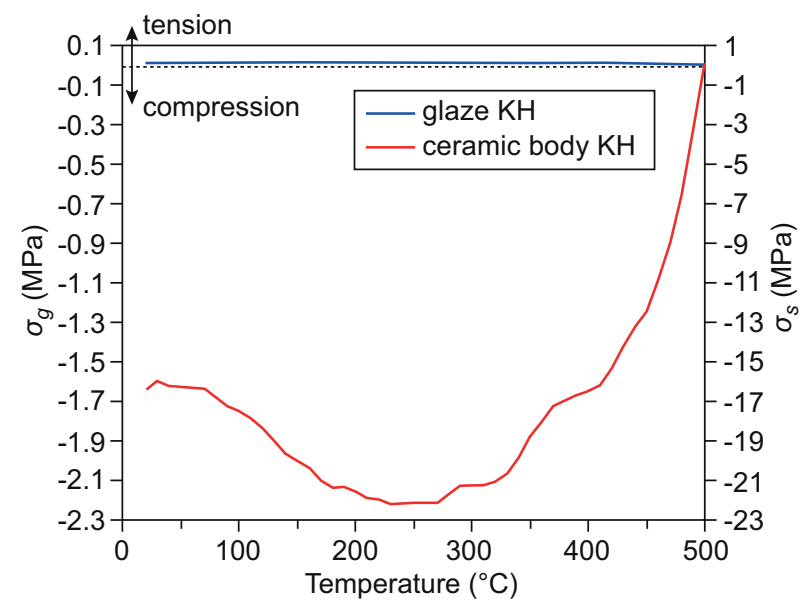

Figure 7. Slight tensile stress within the lead glaze of contemporary ceramic stove, glaze and body layers thicknesses were chosen $h_{g}=200 \mu \mathrm{m}$ and $h_{s}=20000 \mu \mathrm{m}$.

interface was detected. Moreover the stress relieving defects of peeling of the glaze was also observed by stereomicroscope (Figure 8b).

\section{Contemporary ceramic roofing tile}

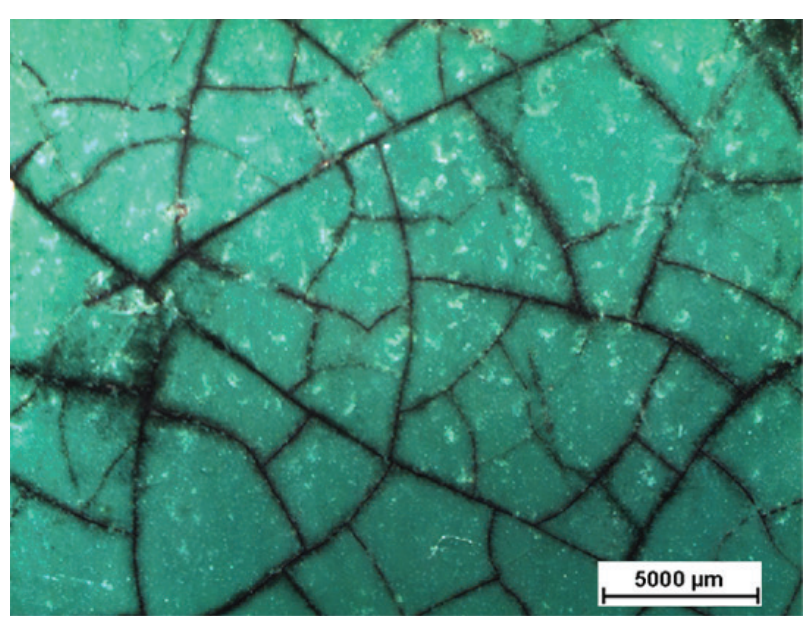

a)

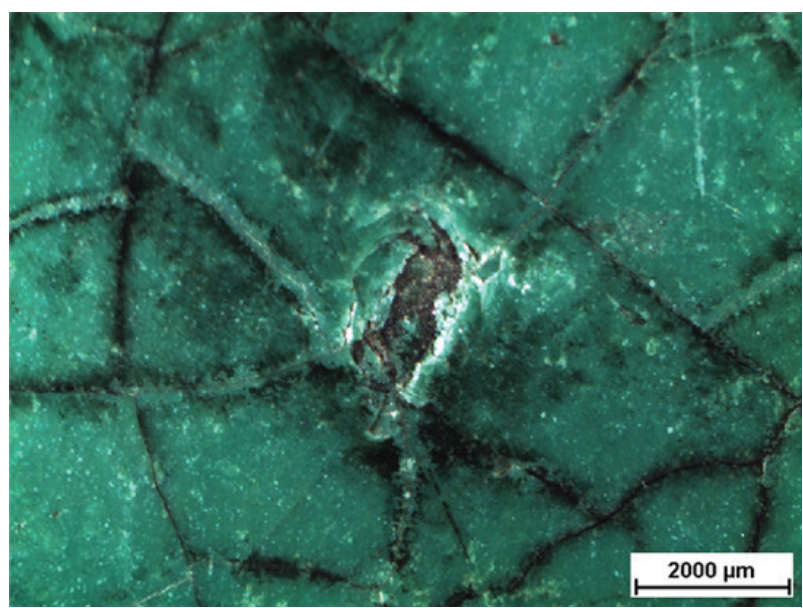

b)

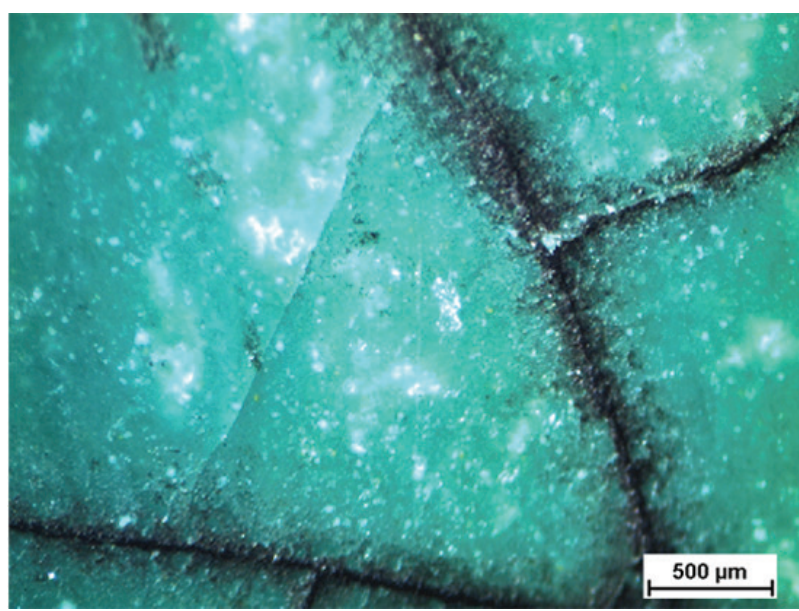

c)

Figure 8. Microscopic evaluation of degraded glaze KH.

The characterization of the glaze and ceramic body properties related to an imposed temperature alteration is crucial for evaluation of stress relations of the glaze - ceramic body system and identification of the defect origin of contemporary building ceramics. This part is focused on the evaluation of glaze - ceramic body system of glazed roof tile. The glaze Gr was selected 
for its ceramic body and is in slight compressive stress immediately after firing (Figure 9). The relative expansion of the glaze $\mathrm{Gr}$ is smaller than expansion of the body $\mathrm{H}$. The calculations of stress relations confirmed the measured relative expansion values and showed that the glaze $\mathrm{Gr}$ is in slight compression of $-0.25 \mathrm{MPa}$ and the ceramic body $\mathrm{H}$ is in tension of $18.9 \mathrm{MPa}$. The overall mismatch of this system is therefore $19.1 \mathrm{MPa}$ from which could be concluded that the glaze was properly chosen for its ceramic body and fulfill its purpose.

The calculation of stress relation confirmed that the glaze $\mathrm{Gr}$ is in slight compression after firing and could be used for appropriate roof tile production (Figure 10).

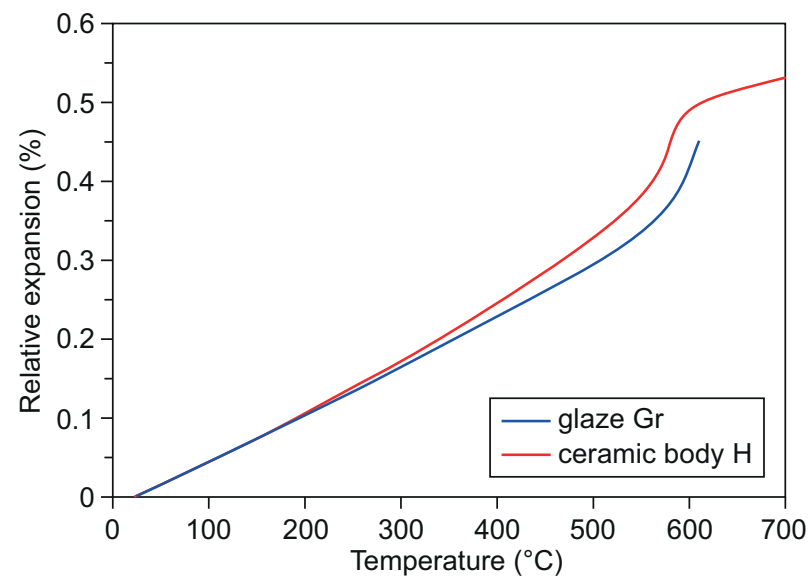

Figure 9. Relative expansion curves of ceramic body and glaze.

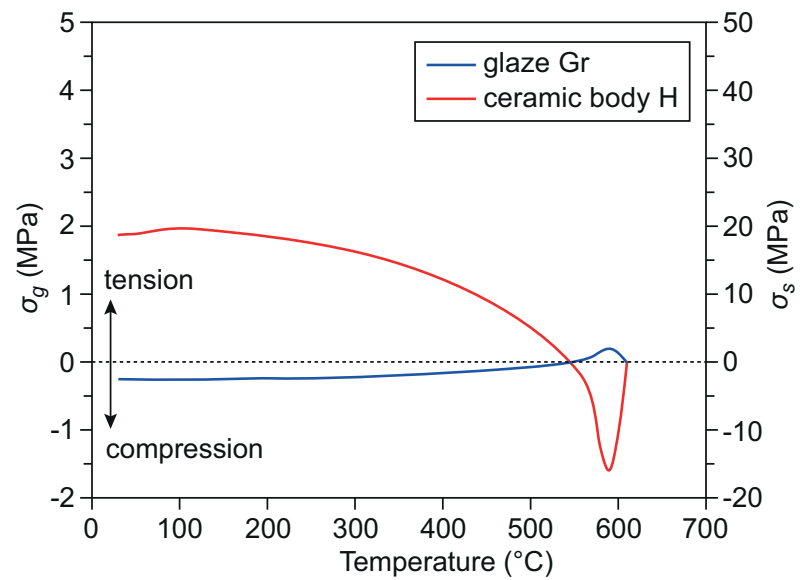

Figure 10. Slight compressive stress within the glaze of roofing tile, glaze and body layers thicknesses were chosen $h_{g}=200 \mu \mathrm{m}$ and $h_{s}=15000 \mu \mathrm{m}$.

\section{Historical ceramic glazed stove S5}

The evaluation of stress relations could be also associated with the characterization of archaeological or historical glazed ceramic fragments. Archaeological ceramic stove tiles are one specific part of archaeological ceramic fragments. The glaze of stove tiles should be in slight tension to serve the typical crazing pattern. The expansion measurements and subsequent calculation of stress relations of several different samples of archaeological stove tiles showed that the glazes of tiles are in tensile stress (Figure 11-12). The established tension-tensile stress of the historical crazing glazes is often observed on the surface due to the formation of characteristic defects.

The stress within the glazes of the tile samples was calculated in the range from 1.5 to $8.2 \mathrm{MPa}$, the ceramic bodies of the investigated tile samples showed the compressive stress in the range from -35 to $-120 \mathrm{MPa}$. Thermally induced residual stress mismatch of tile samples was within the range 38 to $126 \mathrm{MPa}$. All the glazes were crazed to some extend but most of them have poor surface due to deposition in waste pits. The glaze of presented sample tile S5 (Figure 12) was in tensile stress 3.8 $\mathrm{MPa}$ which lead to its crazing. The compressive stress calculated within the ceramic body of tile S5 was

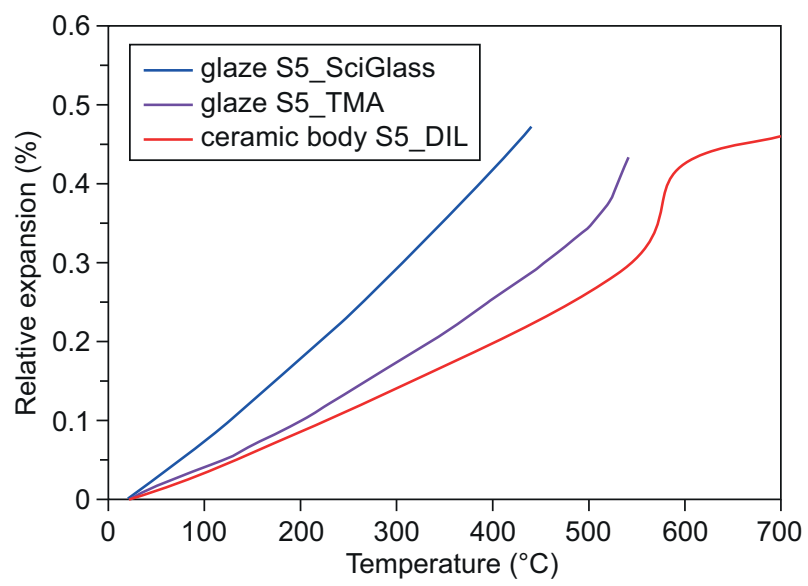

Figure 11. Relative expansion curves of ceramic body and glaze of historical ceramic stove.

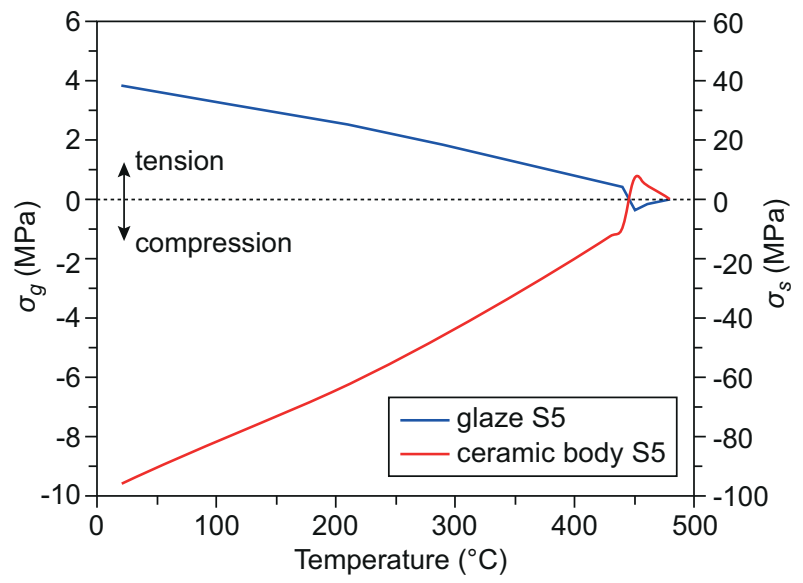

Figure 12. Tensile stress within the glaze of historical stove, glaze and body layers thicknesses were chosen $h_{g}=200 \mu \mathrm{m}$ and $h_{s}=10000 \mu \mathrm{m}$. 
-95.8 $\mathrm{MPa}$ and the thermally induced mismatch was almost $100 \mathrm{MPa}$.

The crazed surface layer was observed by stereomicroscope. The network of fine cracks was detected on the whole surface of several fragments of the tile S5 (Figure 13). Some fragments were also degraded by corrosion layer due to their chemical alteration with the

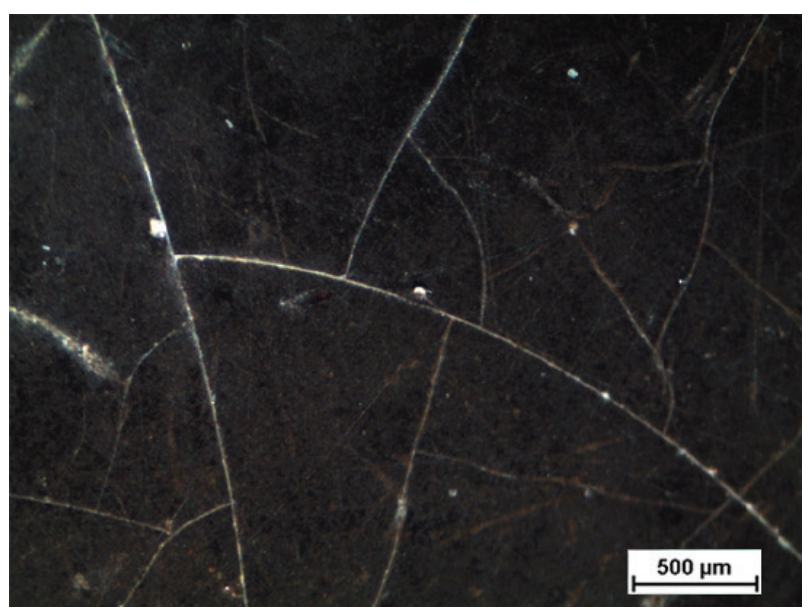

a)

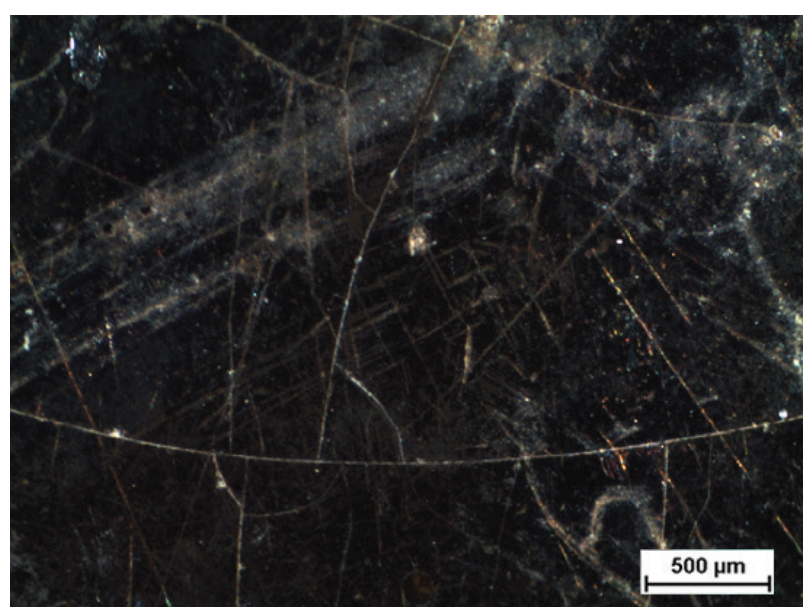

b)

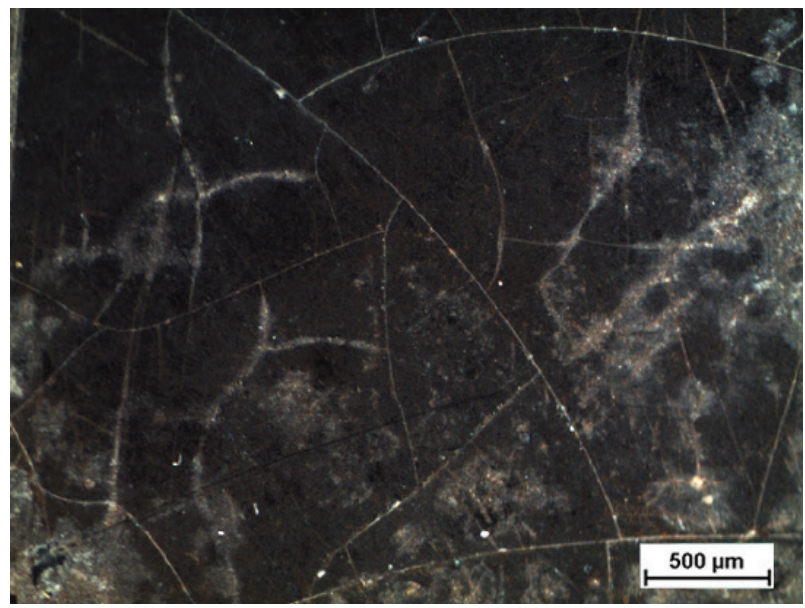

c)

Figure 13. Microscopic evaluation of degraded glaze S5. environment.

\section{Historical glazed floor tile B21a}

The effect of strong compression within the glaze was studied on the samples of archaeological glazed floor tiles B21a which were found during archaeological research of the Břevnov Monastery. The glazed tile samples B21a are a part of a set of fragments of Gothic tiles which constitutes of a ceramic mosaic. The brown glaze of tile B21a was caused by high content of iron oxides which were identified as hematite.

Relative expansion curve of ceramic body was measured by dilatometer and the curve of glaze was calculated from coefficients of thermal expansion which were obtained by the SciGlass program (Figure 14). The expansion of the glaze is apparently lower than that of the ceramic body and the mismatch in thermal expansions generates the compression in the glaze that exceed the strength of adhesion. The stress relation calculations confirmed that the glaze is in the compressive stress of $-4.1 \mathrm{MPa}$ and ceramic body in tensile stress of 101.0 MPa

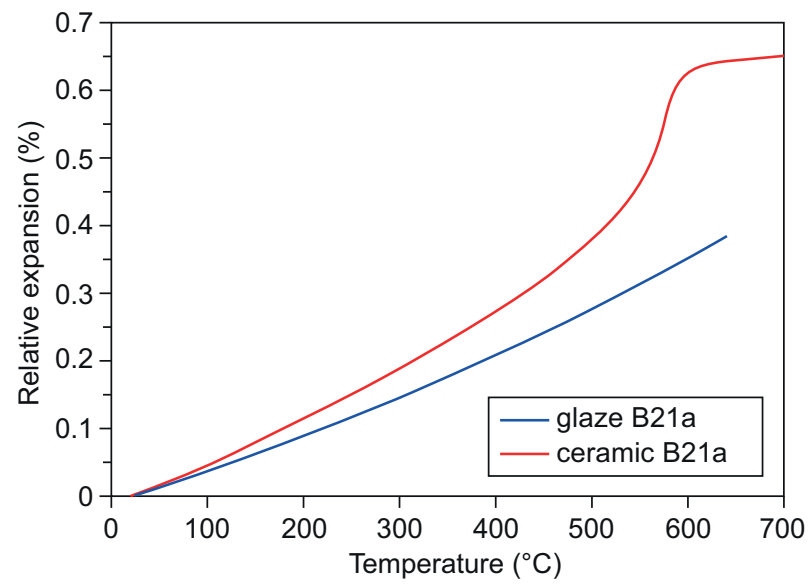

Figure 14. Relative expansion curves of ceramic body and glaze of historical ceramic floor tile.

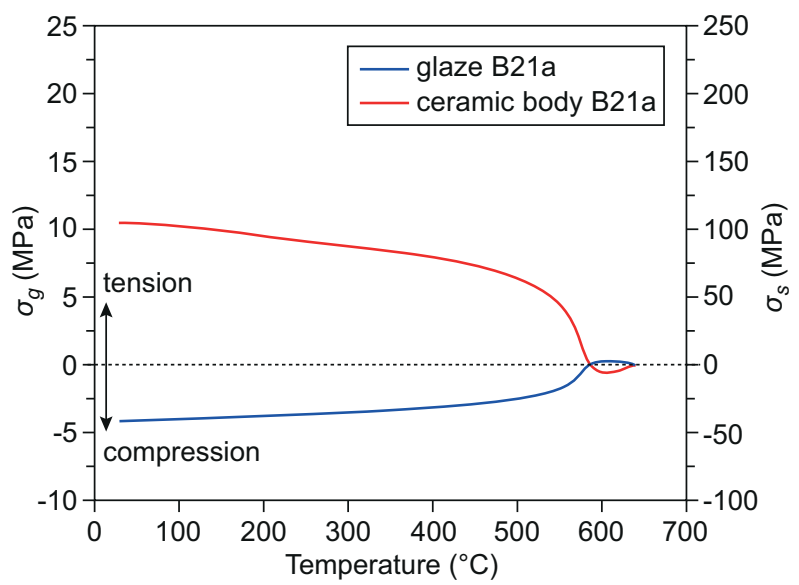

Figure 15. Strong compressive stress within the glaze of floor tile, glaze and body layers thicknesses were chosen $h_{g}=200 \mu \mathrm{m}$ and $h_{s}=5000 \mu \mathrm{m}$. 
(Figure 15). This enormous stress reveals the peeling of the glaze from the surface of the ceramic body.

The stress-relieving defect was studied by stereomicroscope (Figure 16a, 16b) and optical microscope (Figure 16c). The surface of the tile was only partly covered by glaze residues, which were severely crazed. The crazing of the glaze was to some extend supported

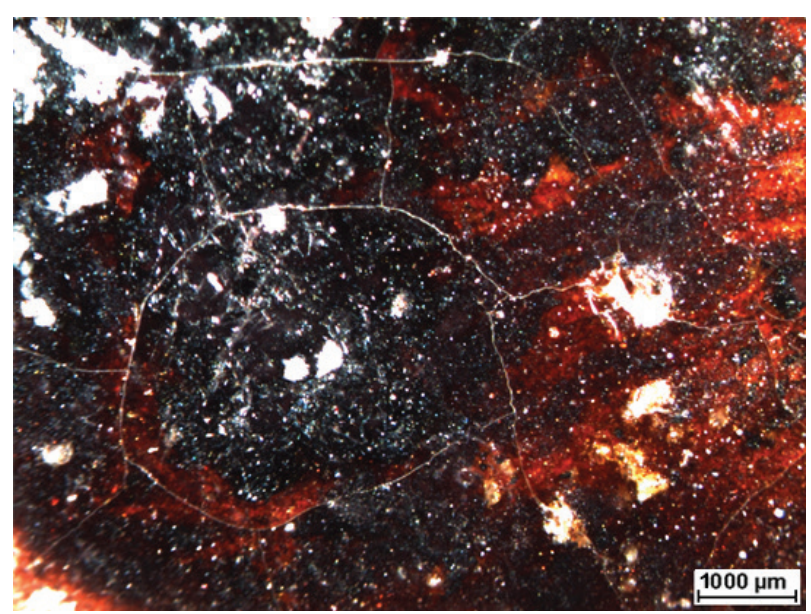

a)

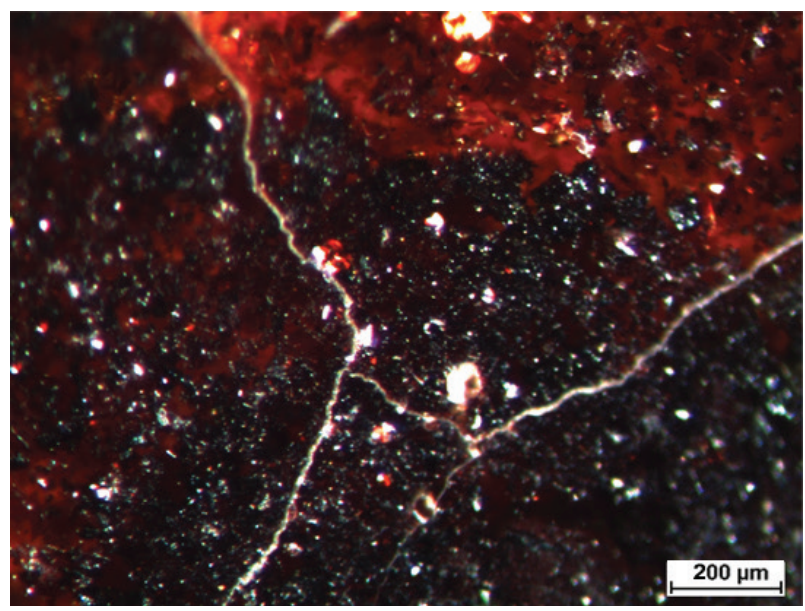

b)

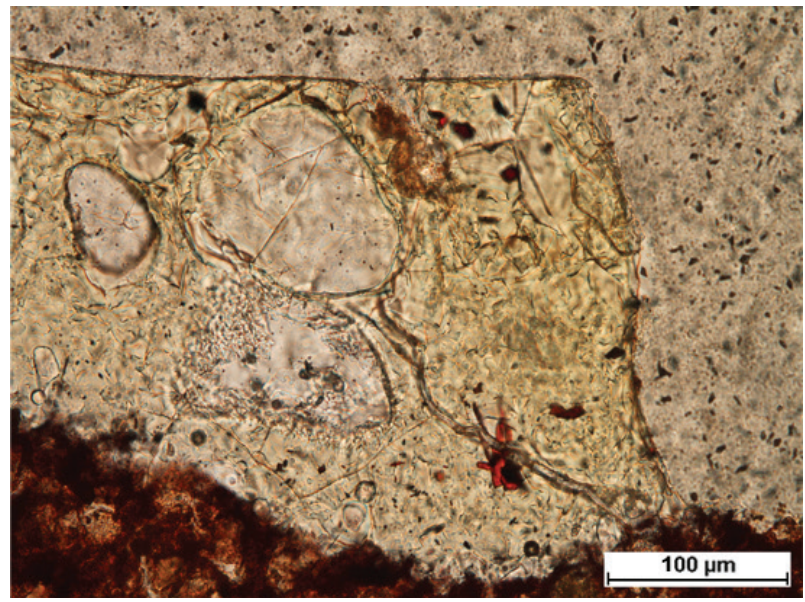

c)

Figure 16. Microscopic evaluation of degraded glaze B21a. by the moisture expansion of its substrate.

\section{CONCLUSION}

The presented work is focused on the characterization of the interaction between glaze and ceramic body. Calculations of stress relations between the body and glaze were firstly performed on model samples of porous ceramics and subsequently applied to real material. Using various model glazes (both lead and lead free), pressure or tensile stresses were created in the surface layers of model systems. The stress state of the model glazed samples was calculated and plotted. The possibility of using TMA measurement and CTE calculations using additive quotients (Sci Glass) for materials for which dilatation measurements cannot be performed (e.g. for historical objects, for complaints, etc.) has been verified. The same procedure for calculating stress states was subsequently applied to historical and contemporary ceramic products exhibiting different types of damage. The calculations of stress relations proved the tensile stresses within glazes of historical and contemporary stove tiles $(3.8$ and $0.05 \mathrm{MPa}$ respectively), which were the source of crazing pattern. Moreover the compression stress in ceramic body of the contemporary glazed stove tile HK was so extensive that caused the subsequent shivering of the glaze. In the case of the Gothic tile, the pressure surge (the value of the mismatch was more than $100 \mathrm{MPa}$ ) in the glaze was the source of peeling. In the case of contemporary roofing, optimal compliance is obtained (the mismatch of values was 19.1 MPa which is the optimal range).

\section{Acknowledgements}

This work was financially supported from specific university research (MSMT No 20/2015). Financial support from specific university research (MSMT No 20-SVV/2016).

\section{REFERENCES}

1. Eppler R. A., Obstler M. (2005). Understanding Glazes. Ohio: The American Ceramic Society, 2005. ISBN 1-57498222-2.

2. Ichiko T. (1994): A Consideration about the Glazing to the Bone China. Journal of the Ceramic Society of Japan, 102(5), 471-475.

3. Inada H. (1977): Relation of Crazing of Porcelain and Stress in Porcelain Glaze, and Method of Rapid Determination of Stress in Porcelain Glaze. Journal of the Ceramic Association, 85(986), 487-496.

4. BannierE., García-Ten J., Castellano J., Cantavella V.(2013). Delayed curvature and residual stresses in porcelain tiles. Journal of the European Ceramic Society, 33(3), 493-501. doi: 10.1016/j.jeurceramsoc.2012.09.018 
5. Fischer H., Hemelik M., Telle R., Marx R. (2005). Influence of annealing temperature on the strength of dental glass ceramic materials. Dental Materials, 21, 671-677. doi: 10.1016/j.dental.2004.09.004

6. Oujiří F. (2005): Napět'ové vztahy v systému střep-glazuragranilie. Zpravodaj Silikátového svazu, 2, 10-20.

7. Kim D., Maeng J., Han Y. S., Kim H., Choi S., Kim H. (2014): Mechanical properties of porcelain with thermally and chemically induced residual stress on glaze. Journal of the Korean Ceramic Society, 51 (5), 487-491.

8. Clark D. E., Zoitos B. K. (1992). Corrosion of Glass, Ceramics and Ceramic Superconductors: Principles, Testing, Characterization and Applications. New Jersey: Noyes Publications. ISBN 0-8155-1283-X.

9. Bonnet C., Bouquillon A., Turrell S. Deram V., Mille B., Salomon J., Thomassin J. H., Fiaud C. (2003). Alteration of lead silicate glasses due to leaching in heated acid solutions. Journal of Non-Crystalline Solids, 323(1-3), 214-220. doi: 10.1016/S0022-3093(03)00279-5

10. Taylor J. R., Bull A. C. (1986). Ceramics glaze technology. Oxford: Pergamon Press. ISBN 0-08-033466-0.

11. Kingery W. D. (1955): Factors Affecting Thermal Stress Resistance of Ceramic Materials. Journal of American Ceramic Society, 38 (1), 3-15.

12. Plešingerová B., Klapáč M., Kovalčíková M. (2002): Moisture expansion of porous biscuit bodies - reason of glaze cracking. Ceramics - Silikáty, 46 (4), $159-165$.

13. Mazurin O. V. (2005): Glass properties: compilation, evaluation, and prediction. Journal of Non-Crystaline Solids, 351, 1103-1112. doi: 10.1016/j.jnoncrysol.2005.01.024 